\title{
Corporate Governance And The Quality Of Financial Disclosures
}

Mark Myring, Ball State University, USA

Rebecca Toppe Shortridge, Northern Illinois University, USA

\begin{abstract}
Congress has recently enacted measures designed to improve corporate governance standards. Regulators have asserted that strong corporate governance enhances the transparency and validity of financial statements. Previous studies addressing the relationship between corporate governance and financial reporting quality yield mixed results. This study employs analyst earnings forecasts to determine whether corporate governance procedures impact the quality of accounting information. Following the work of Barron et al. (1998), we examined the impact of various measures of the strength of corporate governance on forecast accuracy and dispersion. Our results provide mixed evidence to support the notion that the strength of corporate governance impacts the quality of financial statement information.
\end{abstract}

Keywords: Financial Analysts, Corporate Governance

\section{INTRODUCTION}

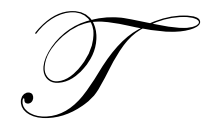

he headlines reporting corporate abuse and fraud seem to be a daily event in recent years. John and Tim Rigas, executives at Adelphia Communications, received prison sentences of 15 and 20 years for looting the cable company. Tyco CEO Dennis Kozlowski and CFO Mark Swartz were convicted of grand larceny for taking hundreds of millions of dollars from shareholders. Bernie Ebbers, CEO of WorldCom, allowed an $\$ 11$ billion accounting fraud to occur that resulted in the loss of $\$ 180$ billion of shareholder value as stock prices plummeted. And, perhaps, the most notable case, Kenneth Lay and Jeffrey Skilling, former CEOs of Enron, were both convicted of fraud and conspiracy that eventually led to the bankruptcy of Enron, once the $7^{\text {th }}$ largest company on the S\&P 500. According to Nell Minow from The Corporate Library, "these companies came to symbolize a breakdown in corporate governance that rocked stock prices and investor confidence" (Loomis 2004).

These and other scandals prompted a wave of regulations to promote corporate responsibility. Specifically, Congress passed the Sarbanes-Oxley Act (SOX) in 2002. One of the primary objectives of this initiative was to enhance the validity of information reported to shareholders by requiring corporate boards to be more responsible for the behavior of their CEO. Regulators hope that implementation of these policies will result in improved financial disclosures, reduced fraudulent activity, and stronger financial markets.

Compliance with these standards, however, is expensive. According to a survey by RHR International, companies with more than $\$ 4$ billion in revenues spend an average of $\$ 35$ million to comply with Sarbanes-Oxley (Henry and Borrus 2005). HI/fn, a computer security company with $\$ 40$ million in revenue, reported that in-house documentation of SOX 404 resulted in an expense of $\$ 200,000$ (Cheney 2004). According to William R. Walker, chief financial officer and secretary of Hi/fn, "[SOX Section 404] is a very expensive operation for small companies. It's hard intellectually to argue against good internal controls, but the costs, with minimal value, are significant" (Cheney 2004). Walker's sentiment is not uncommon. The cost of compliance with SOX has caused many small firms to 'go dark' - de-register with the SEC and de-list from major exchanges (Marosi and Massoud 2004). Thus, it is important to evaluate if enhanced corporate governance actually generates the desired outcome. This study, therefore, examines if strong corporate governance improves the financial reporting environment of markets. 
Research that evaluates the impact of corporate governance policies on the financial reporting environment generates mixed evidence. Karamanou and Vafeas (2005) demonstrated that corporations with more efficient boards and stronger audit committees led to the issuance of more forecasts by management that were also more accurate. Contrary to these results, research by Koehn and Ueng (2005) documented that firms with poor governance practices provided financial information that was at least as good as firms with strong corporate governance. In addition, Farber (2005) found that firms previously cited for fraud had difficulty overcoming the stigma, even after improving their corporate governance practices. Specifically, they still faced issues with credibility as institutional holdings and the number of analysts following the company did not increase subsequent to governance improvements. Thus, it is not clear whether stronger corporate governance directives accomplish the desired goal of creating more transparent and reliable financial statements.

Holthausen and Watts (2001) strongly advocated the use of research methods that do not rely on capital market data to assess the relative quality of financial disclosures, especially when research using capital markets data yields inconclusive results. Recent research (e.g., Barron et al. 2002) examined analyst's reliance on financial statements to measure the quality of financial disclosures. Analysts are market intermediaries that aggregate both financial and non-financial information to derive estimates of earnings. Behavior of analysts provides insight into the activities and beliefs of investors that cannot be directly observed (Nichols 1989). Thus, we utilize analysts' earnings forecasts to provide an alternative framework for examining the impact of corporate governance on financial markets.

Using data from The Corporate Library, an investment research firm that grades the corporate governance structures of U.S. companies, we empirically examined the impact of strong corporate governance on financial reporting by assessing the analysts' information environment. Higher quality information, an assumed product of strong corporate governance, should reduce analysts' need to obtain external, idiosyncratic information.

Our results provide mixed evidence on the relationship between corporate governance and the quality of financial disclosures. Specifically, governance scores from The Corporate Library tend not to be related to analysts' consensus or the accuracy of individual forecasts. In fact, the only governance attribute that appears to impact uncertainty is the number of "best practices" followed by our sample companies. These results are consistent with those reported by Koehn and Ueng (2005) and Farber (2005) that suggested that strong corporate governance policies may not result in improvements in the financial reporting environment.

\section{DEVELOPMENT OF HYPOTHESES AND METHODOLOGY}

Analytical studies of analysts' behavior provide mathematical models that illustrate the relationship between information quality and the characteristics of earnings forecasts (see Diamond 1985, Kim and Verrecchia 1997). These models show that analysts use two types of information to produce earnings estimates: information that is available to all analysts (i.e., common information) and information that is privately obtained or generated and, therefore, is not available to all analysts (i.e., idiosyncratic information). Publicly released financial statements are an example of common information. An example of idiosyncratic information is that obtained directly from interviews with a company's management.

Analysts are motivated to efficiently use all sources of information (both common and idiosyncratic) to produce the most accurate earnings forecasts. In settings where common disclosures are of inferior quality, analysts will tend to make less accurate forecasts (Barron et al. 1998). The quality of common information has also been shown to affect analysts' reliance on idiosyncratic (private) information. Specifically, analysts place more emphasis on idiosyncratic information when common information is of low quality (Barron et al. 2002). Thus, an increase in analysts' use of idiosyncratic information results in greater dispersion of earnings forecasts (Barron et al. 1998).

We assume that stronger corporate governance results in higher quality financial information. Analysts will make more accurate forecasts for firms with strong corporate governance. Under this assumption, analysts are expected to place greater priority on obtaining private information for firms with weak corporate governance because the financial statements (i.e., common information) are low quality. Because analysts are expected to use more idiosyncratic information when firms have poor governance structures, analysts' forecasts for these firms are 
likely to have increased uncertainty and greater dispersion (less consensus). Thus, we evaluate the effect of corporate governance on the financial reporting environment by measuring the impact of corporate governance ratings on analysts' consensus and uncertainty. We test two hypotheses: (1) weak corporate governance will result in lower consensus among analysts and (2) aggregate analysts' forecasts will be more accurate than individual forecasts by a larger margin when corporate governance is weak.

\section{Dependent variables}

Our measures for consensus and uncertainty are derived from Barron et al. (1998) and Barron et al. (2002). They demonstrated that consensus and uncertainty can be measured in terms of three forecast properties: expected dispersion, expected squared error in the mean forecast, and the number of analysts issuing forecasts, N. Relying on this methodology we utilized the dependent variables established by Barron et al. (2002):

U-SE : a measure of the benefits of aggregating individual analysts' forecasts (uncertainty), and

$\rho: \quad$ a measure based on observed values of forecast dispersion and the squared error in the mean forecast

where: (consensus).

$U=\left(1-\frac{1}{N}\right) \hat{D}+\hat{S E}$

$\rho=\frac{\hat{S E}-\frac{\hat{D}}{N}}{\left(1-\frac{1}{N}\right) \hat{D}+\hat{S E^{\prime}}}$

$\hat{D}_{i t}=\frac{1}{N_{i t}-1} \sum_{i=l}^{N}\left(F_{j i t}-\bar{F}_{i t}\right)^{2}$,

$\hat{E}_{i t}=\left(A_{i t}-\bar{F}_{i t}\right)^{2}$.

and:

$\hat{D}_{i t}$ is the observed dispersion among the forecasts for firm $i$ in

year $t$;

$S \hat{E}_{i t}$ is the observed squared error in the mean forecast for firm $i$

in year $t$;

$N_{i t}$ is the observed number of forecasts we use for firm $i$ in year $t$;

$F_{j i t}$ is the forecast from analyst $j$ for firm $i$ in year $t$;

$F_{i t}$ is the mean of the forecasts for firm $i$ in year $t$; and

$A_{i t}$ is the actual earnings for firm $i$ in year $t$. 


\section{Independent variables}

We are interested in measuring the impact of corporate governance on the information environment of analysts. We utilized corporate governance ratings from the The Corporate Library as our primary independent variable. The Corporate Library developed a proprietary ratings formula to identify potential problems with board effectiveness. Their ratings formula is a compilation of seven categories that are indicative of board effectiveness: board composition, CEO compensation, shareholder responsiveness, accounting, strategic decision making, litigation and regulatory problems, and takeover defenses. Relying on key evaluators, their approach identified potential problems at Enron, Worldcom, Global Crossing, and others before their collapse. Our primary variable of interest is the overall governance score received by the rated companies. We also evaluated the seven component scores as a supplemental test. Finally, as an alternative to the The Corporate Library grade, we assessed if the "Best Practice Compliance Score" for each company is related to uncertainty and consensus in the information environment.

\section{Control Variables}

We incorporated numerous control variables that have been shown to impact the information environment of analysts. The first two control variables measure the time-series variability in earnings of the sample firms. SDEPS $_{\mathrm{j}, \mathrm{t}}$ is the standard deviation of annual earnings per share over the three years prior to the research period deflated by annual EPS in the year prior to the start of the research period. $\mathrm{CHNI}_{\mathrm{j}, \mathrm{t}}$ is the absolute value of the change in annual EPS between the year t-1 and year t-2 deflated by EPS at $\mathrm{t}-2$. Greater variability in earnings (as evidenced by higher $\operatorname{SDEPS}_{\mathrm{j}, \mathrm{t}}$ and CHNI $\mathrm{j}, \mathrm{t}$ ) indicate that prior year's earnings are potentially less useful as a predictor of future earnings. This may encourage market participants to increase their private information acquisition activities (Barron et al. 2002).

The remaining control variables have been shown to impact accuracy and/or forecast dispersion in previous research. $\mathrm{NUM}_{\mathrm{j}, \mathrm{t}}$ is the number of analysts providing earnings forecasts. Lang and Lundholm (1996) found that firms with high quality financial disclosure have a greater number of analysts following, more earnings forecast accuracy and less dispersion among analysts' forecasts. $\mathrm{MKTCAP}_{\mathrm{j}, \mathrm{t}}$ is the market value of equity at time $\mathrm{t}-1$. Lang and Lundholm (1996) also demonstrated that larger firms have greater forecast accuracy. In addition, Barron et al. (2002) used market to book, MKBK, to proxy for firm growth opportunities. Growth firms have a greater analyst following, indicating greater investor demand for private information. Finally, we included the percent of inside directors, \%INSIDE, as a control variable because many view board independence as a necessary condition for strong corporate governance (Uzun et al. 2004).

\section{SAMPLE AND DESCRIPTIVE STATISTICS}

Our sample is comprised of firms that have data available from the Corporate Library, Compustat, and the Institutional Brokers Estimates Systems (I/B/E/S). The Corporate Library contains evaluations of the governance structures of sample firms after evaluating the seven component ratings. Firms with excellent corporate governance ratings receive a grade of $\mathrm{A}$ while those with poor governance structures receive a grade $\mathrm{F}$. In order to complete our evaluation, we transformed grades of A's into a governance score of 5, and those with F's into a governance score of 1. We calculated the market capitalization of sample firms as well as their market to book ratios using data from Compustat. We obtained analysts forecast of EPS, actual EPS and the number of analysts following a firm from the $\mathrm{I} / \mathrm{B} / \mathrm{E} / \mathrm{S}$ database. Matching across the three data sources resulted in a final sample of 1,150 firms with complete observations.

The descriptive statistics for the sample firms are provided in Table 1. The sample firms exhibit a fair amount of time-series variability in earnings, with the average (median) value of $\mathrm{CHNI}_{\mathrm{j}, \mathrm{t}}$ taking a value of 1.239 (0.445). In addition, their three year standard deviation in earnings is relatively high. Firms tend to be large (average market capitalization of 2,407 million dollars) and have a relatively large high number of analysts following. 
Table 1: Descriptive Statistics

\begin{tabular}{|lccccc|}
\hline \multicolumn{1}{|c}{ Variable } & Mean & Median & SD & $\mathbf{7 5 \%}$ & 25\% \\
\hline $\mathrm{m}(\mathrm{U}-\mathrm{SE})_{\mathrm{i}}$ & -0.022 & 0.001 & 2.407 & 0.009 & -0.001 \\
$\mathrm{~m}(\rho)_{\mathrm{i}}$ & 0.364 & 0.336 & 0.59 & 0.691 & 0.003 \\
$\mathrm{NUM}_{\mathrm{i}}$ & 11.267 & 9.000 & 7.276 & 15 & 6 \\
$\mathrm{SDEPS}_{\mathrm{i}}$ & 0.561 & 0.300 & 0.479 & 0.630 & 0.280 \\
$\mathrm{CHNI}_{\mathrm{i}}$ & 1.239 & 0.445 & 2.581 & 1.072 & 0.184 \\
$\mathrm{MKTCAP}_{\mathrm{i}}$ & 2,407 & 1,413 & 2,996 & 2,716 & 704 \\
$\mathrm{MKBK}_{\mathrm{i}}$ & 3.156 & 2.571 & 1.979 & 3.901 & 1.302 \\
\%INS $_{\mathrm{i}}$ & 0.122 & 0.055 & 0.174 & 0.137 & 0.024 \\
BEST $_{\mathrm{i}}$ & 84.846 & 86.000 & 8.631 & 91.000 & 80.000 \\
CGRATE $_{\mathrm{i}}$ & 3.534 & 3.556 & 0.381 & 4.105 & 3.308 \\
\hline
\end{tabular}

Variables are defined as follows: $\mathrm{m}(\mathrm{U}-\mathrm{SE})_{\mathrm{I}}=$ mean of the U-SE variable defined in equations 1 and $4, \mathrm{~m}(\rho)_{\mathrm{I}}=\mathrm{mean}$ of the $\rho$ variable defined in equation $2, \mathrm{NUM}_{\mathrm{i}}=$ number of analysts following the firm, $\mathrm{SDEPS}_{\mathrm{i}}=$ the standard deviation of EPS for the past 3 years, $\mathrm{CHNI}_{\mathrm{i}}=$ absolute value of change in earnings, $\mathrm{MKTCAP}_{\mathrm{i}}=$ market capitalization in millions of dollars, $\mathrm{MKBK}_{\mathrm{i}}=$ market value of firm deflated by to book value of equity, $\% \mathrm{INS}_{\mathrm{i}}=\%$ insiders on board of directors, $\mathrm{BEST}_{\mathrm{i}}=\%$ of corporate governance best practices followed, provided by The Corporate Library, CGRATE $\mathrm{C}_{\mathrm{i}}=$ average of individual corporate governance grades provided by The Corporate Library.

The corporate governance characteristics reveal some interesting facts about our firms. On average, the boards of directors of our sample companies are composed of $12.2 \%$ insiders. In addition, the sample firms follow approximately $85 \%$ of the best practices defined by the Corporate Library database ${ }^{1}$. Finally, the firms received an average aggregate corporate governance grade of 3.534 , or an average grade of $\mathrm{C}$. Interestingly, according to the best practices checklist, the average grade would be a B.

\section{RESULTS}

Consistent with prior research (e.g., Barron et al. 2002) ranked regression is used in our primary analysis. Table 2 provides results of a ranked regression of the relationship between corporate governance measures and information properties of analysts' forecasts. The dependent variable in Columns 1 and 2 is dispersion of analysts' forecasts. The regression results indicate that dispersion in analysts' forecasts are positively related to the number of analysts following the company, NUM, and the variability in net income, CHNI. Further, as the size of the corporation increases, the dispersion of analysts' forecasts decreases. Contrary to our expectations, dispersion is not related to the two variables of interest: the percent of best practices an organization follows, BEST, or to their corporate governance rating, CGRATE. These results suggest that the accuracy of analyst forecasts are not impacted by variation corporate governance structures.

Columns 3 and 4 of Table 2 provide the rank regression results for the relationship between corporate governance measures and analysts consensus. Complimenting the results presented above, consensus is negatively correlated with the number of analysts following the company, NUM, and with the variability in net income, CHNI. The size of the company, MKTCAP, is not related to analysts' consensus. In contrast to the previous regressions, we find some evidence of a relationship between forecast dispersion and the variables of interest. Specifically, the percent of corporate governance best practices followed, BEST, is modestly related to analysts' consensus. However, the coefficient on CGRATE is not significant. These results suggest that there is limited evidence of a relation between corporate governance quality and the characteristics of analyst forecasts.

\footnotetext{
${ }^{1}$ The Corporate Library established a best practice compliance checklist that includes 21 yes or no items. For example, are the CEO and Chairman of Board roles separated? The list of items is similar to that developed by the Organization for Economic Collaboration and Development.
} 
Table 2: Rank Regression Analysis of Cross-Sectional Relationship Between Aggregate Corporate Governance Measures and Information Properties of Analysts' Forecasts

\begin{tabular}{|c|c|c|c|c|}
\hline \multirow[b]{2}{*}{ Ind. Variables: } & \multicolumn{4}{|c|}{ Dependent Variables: } \\
\hline & $\mathrm{m}(\mathrm{U}-\mathrm{SE})_{\mathrm{i}}$ & & $\mathrm{m}(\rho)_{\mathrm{i}}$ & \\
\hline \multirow[t]{2}{*}{ INT. } & 471.69 & 545.60 & 861.42 & 601.73 \\
\hline & $(105.9)^{*}$ & $(96.1)^{*}$ & $(7.72)^{*}$ & $(5.93)^{*}$ \\
\hline \multirow[t]{2}{*}{$\mathrm{NUM}_{\mathrm{i}}$} & 0.159 & 0.157 & -0.069 & -0.064 \\
\hline & $(4.78)^{*}$ & $(4.73)^{*}$ & $(-1.97)^{* *}$ & $(-1.83)^{*}$ \\
\hline \multirow[t]{2}{*}{ SDEPS $_{\mathrm{i}}$} & -0.046 & -0.046 & 0.061 & 0.061 \\
\hline & $(-1.35)$ & $(-1.35)$ & $(1.69)^{* * *}$ & $(1.68)^{* * *}$ \\
\hline \multirow[t]{2}{*}{$\mathrm{CHNI}_{\mathrm{i}}$} & 0.192 & 0.193 & -0.061 & -0.065 \\
\hline & $(5.98)^{*}$ & $(6.00)^{*}$ & $(-1.82) * * *$ & $(-1.92)^{* * *}$ \\
\hline \multirow[t]{2}{*}{ MKTCAP $_{\mathrm{i}}$} & -0.278 & -0.277 & -0.019 & -0.019 \\
\hline & $(-8.17)^{*}$ & $(-8.14)^{*}$ & $(-0.53)$ & $(0.53)$ \\
\hline \multirow[t]{2}{*}{$\mathrm{MKBK}_{\mathrm{i}}$} & -0.028 & -0.028 & 0.023 & 0.020 \\
\hline & $(-0.92)$ & $(-0.92)$ & $(0.73)$ & $(0.64)$ \\
\hline \multirow[t]{2}{*}{$\% \mathrm{INS}_{\mathrm{i}}$} & 11.44 & -6.075 & -67.08 & -16.44 \\
\hline & $(0.20)$ & $(-0.11)$ & $(-1.10)$ & $(-0.28)$ \\
\hline \multirow[t]{2}{*}{$\mathrm{BEST}_{\mathrm{i}}$} & 1.313 & & -2.767 & \\
\hline & (1.13) & & $(-2.27)^{* *}$ & \\
\hline \multirow[t]{2}{*}{ CGRATE } & & 11.24 & & 5.489 \\
\hline & & $(0.44)$ & & $(0.21)$ \\
\hline $\operatorname{Adj} R^{2}$ & 0.1054 & 0.1046 & 0.0075 & \\
\hline
\end{tabular}

t-statistics in parentheses. $*, * * * * *$ reflect significance at the $0.01,0.05$, and 0.10 , respectively

Karmanou and Vafeas (2005) documented that management forecasts were more accurate when corporations had more efficient boards and stronger audit committees. Vermeer (2005) found that companies making voluntary $\mathrm{CEO} / \mathrm{CFO}$ certifications engaged in less income-increasing earnings management. Hence, we also investigated if individual corporate governance mechanisms are related to dispersion and consensus in analysts' forecasts.

Table 3 reports the results from regressing dispersion and consensus on The Corporate Library's seven component ratings. Consistent with the results of Table 2, many of the control variable are significantly related to analyst forecasts accuracy and dispersion. Moving to the analysis of the disaggregated corporate governance grades, we find little evidence of a relationship between corporate governance and forecast accuracy. Specifically, no significant relationships are indentified between analyst forecast accuracy and corporate governance measures. In the dispersion regressions, the only relationship that was marginally significant was between consensus and Litigation and Regulatory Problems, LITPROB. Firms with fewer litigation and regulatory issues had greater consensus among analysts. Overall, the results of this analysis provide extremely weak evidence of a relation between corporate governance and analyst forecast characteristics.

Overall, the results reported in Tables 2 and Table 3 are somewhat consistent with those discussed by Koehn and Ueng (2005) and Farber (2005). In both of those papers, stronger corporate governance directives did not appear to contribute to more transparent and reliable financial statements. Our results indicate that stronger corporate governance ratings, as evaluated by The Corporate Library, do not seem to influence the information environment faced by analysts.

\section{CONCLUSION}

Changes in corporate regulations to reduce weaknesses in financial reporting are not new. Nearly 100 years ago, the McKesson Robbins scandal led to Statements on Auditing Procedures that required auditors to observe inventories and confirm receivables (Arens and Elder 2006). Several allegations of fraud occurred in the 1980's that resulted in standards requiring auditors to understand controls and to perform analytical procedures (Arens and Elder 2006). The requirements of Sarbanes-Oxley, in many ways, extend regulations that were a result of prior scandals in the accounting information environment. 
Table 3: Rank Regression Analysis of Cross-Sectional Relationship Between Disaggregated Corporate Governance Measures and Information Properties of Analysts' Forecasts

\begin{tabular}{|c|c|c|}
\hline \multirow[b]{2}{*}{ Ind. Variables: } & \multicolumn{2}{|c|}{ Dependent Variables: } \\
\hline & $\mathrm{m}(\mathrm{U}-\mathrm{SE})_{\mathrm{i}}$ & $\mathrm{m}(\rho)_{\mathrm{i}}$ \\
\hline \multirow[t]{2}{*}{ INT. } & 401.1 & 736.54 \\
\hline & $(2.69)^{*}$ & $(4.41)^{*}$ \\
\hline \multirow[t]{2}{*}{$\mathrm{NUM}_{\mathrm{i}}$} & 0.158 & -0.066 \\
\hline & $(4.73)^{*}$ & $(-1.87) * * *$ \\
\hline \multirow[t]{2}{*}{ SDEPS $_{\mathrm{i}}$} & -0.047 & 0.062 \\
\hline & $(-1.38)$ & $(1.72)^{* * *}$ \\
\hline \multirow{2}{*}{$\mathrm{CHNI}_{\mathrm{i}}$} & 0.194 & -0.064 \\
\hline & $(6.03)^{*}$ & $(-1.87) * * *$ \\
\hline \multirow[t]{2}{*}{ MKTCAP $_{\mathrm{i}}$} & -0.276 & -0.018 \\
\hline & $(-8.09)^{*}$ & $(-0.49)$ \\
\hline \multirow[t]{2}{*}{$\mathrm{MKBK}_{\mathrm{i}}$} & -0.028 & 0.019 \\
\hline & $(-0.91)$ & $(0.60)$ \\
\hline \multirow[t]{2}{*}{$\% \mathrm{INS}_{\mathrm{i}}$} & 22.38 & -58.44 \\
\hline & $(0.37)$ & $(-0.92)$ \\
\hline \multirow[t]{2}{*}{ BDEFF } & -6.03 & 4.67 \\
\hline & $(-0.40)$ & $(0.29)$ \\
\hline \multirow[t]{2}{*}{ BDCOMP } & 11.88 & -4.52 \\
\hline & $(0.98)$ & $(-0.35)$ \\
\hline \multirow[t]{2}{*}{ CEOCOMP } & -2.44 & -1.80 \\
\hline & $(-0.24)$ & $(-0.17)$ \\
\hline \multirow[t]{2}{*}{ SHREP } & 18.62 & -6.57 \\
\hline & $(0.76)$ & $(-0.25)$ \\
\hline \multirow[t]{2}{*}{ LITPROB } & 2.72 & 32.11 \\
\hline & $(0.15)$ & $(1.69)^{* * *}$ \\
\hline \multirow[t]{2}{*}{ TAKEOVER } & 11.47 & -12.09 \\
\hline & $(1.16)$ & $(-1.16)$ \\
\hline \multirow[t]{2}{*}{ ACC } & -8.24 & 5.20 \\
\hline & $(-0.97)$ & $(0.58)$ \\
\hline \multirow[t]{2}{*}{ STRAT } & 19.44 & -45.55 \\
\hline & $(0.70)$ & $(-1.54)$ \\
\hline $\operatorname{Adj} R^{2}$ & 0.1027 & 0.0022 \\
\hline
\end{tabular}

t-statistics in parentheses.*, **, *** reflect significance at the $0.01,0.05$, and 0.10 , respectively, based on two-tailed tests. Additional variables are defined as follows: BDEFF $=$ average board effectiveness grade, BDCOMP = board composition, $\mathrm{CEOCOMP}=\mathrm{CEO}$ compensation, $\mathrm{SHREP}=$ shareholder responsiveness, LITPROB = litigation and regulatory Problems, TAKEOVER $=$ takeover defenses, $\mathrm{ACC}=$ accounting quality, STRAT $=$ strategic decision making.

The benefits of increased regulation and corporate governance scrutiny are difficult to measure. As Henry and Borrus (2005) point out, "the promised benefits of the reform movement are hard to spot and difficult to quantify: frauds that never happened, or the boost to investor confidence that has helped bring life back to U.S. markets." Prior empirical research examining the benefits from strong corporate governance provide mixed results. The current paper evaluates the impact of corporate governance ratings, developed by The Corporate Library, on the information environment of analysts. We postulate that stronger corporate governance will lead to improved financial reporting. Enhanced financial reporting should result in less dispersion and greater consensus in analysts' forecasts as they seek less idiosyncratic information. The results provide only weak evidence of a relation between corporate governance and enhanced financial disclosure.

Despite our results and those of Koehn and Ueng (2005) and Farber (2005), Sarbanes-Oxley and the increased emphasis on improving corporate governance are likely to remain. Even though these new regulations may not alter the information environment of analysts, they are likely to result in better-managed companies that act as good corporate citizens. According to Cheney, "some see the measures as not much more than cost without benefit" however, "companies are hoping that better governance and internal controls will improve public perception and attract investment (Cheney 2004). 


\section{ACKNOWEDGEMENT}

We gratefully acknowledge the contributions of $I / B / E / S$ International Inc. for providing earnings per share forecast data from their Institutional Brokers Estimate System. This data has been provided as part of a broad academic program to encourage earnings expectations research.

\section{AUTHOR INFORMATION}

Dr. Mark Myring joined the Ball State accounting faculty in 2000. He received a BSBA in accounting from John Carroll University in 1995, an MBA from Kent State University in 1999 and a Ph.D. from Kent State University in 2000. Dr. Myring's current research focuses on the use of accounting information and analysts' forecasts for security valuation in U.S. and international capital markets and the accounting standard setting process in both the U.S. and emerging economies. His work has been published in academic accounting journals and presented at academic conferences.

Dr. Rebecca Shortridge is the Gaylen and Joanne Larson Professor of Accountancy at Northern Illinois University. Dr. Shortridge joined Northern Illinois University in 2005 after working at Ball State University for five years. Rebecca earned a BS in Accounting from Indiana University, an MBA from Indiana University, and a Ph.D. from Michigan State University. Her research primarily focuses on the use of supplemental information by capital markets. She also works extensively developing methods to teach fair value concepts and business valuation to accounting students.

\section{REFERENCES}

1. Arens, A. and R. J. Elder. 2006. Perspectives on Auditing Education after Sarbanes-Oxley. Issues in Accounting Education 21(4): 345-362.

2. Barron, O. D. Byard, C. Kile and E. Riedl. 2002. High-technology intangibles and analysts' forecasts. Journal of Accounting Research 40(2) 289-312.

3. Barron, O., O. Kim, S. Lim and D. Stevens. 1998. Using analysts' forecast to measure properties of analysts' information environment. The Accounting Review 73(4): 421-433.

4. Cheney, G. 2004. FEI poll: Better governance is costing companies more. Accounting Today 18 (Oct 1124).

5. Diamond, D. 1985. Optimal release of information by firms. Journal of Finance 40(September): 10711094.

6. Farber, D. 2005. Restoring trust after fraud: Does corporate governance matter. The Accounting Review 80(2): 539-561.

7. Henry, D. and A. Borrus. 2005. No escaping Sarbanes-Oxley. Business Week Online (January 6). http://web35epnet.com/DeliveryPrintSave.asp?tb=1\&_ug=sid+C09D6618-6B2B-40AE-B (obtained 7/15/2005).

8. Holthausen, R. and R. Watts. 2001. The relevance of the value-relevance literature for financial accounting standard setting. Journal of Accounting and Economics 31: 3-75.

9. Karamanou, I. and N. Vafeas. 2005. The association between corporate boards, audit committees, and management earnings forecasts: An empirical analysis. Journal of Accounting Research 43(3): 453-486.

10. Kim, O. and R. Verrecchia. 1997. Pre-announcement and event period private information. Journal of Accounting and Economics 24: 395-419.

11. Koehn, D. and J. Ueng. 2005. Evaluating the evaluators: Should investors trust corporate governance metrics ratings? Journal of Management and Governance 9: 111-128.

12. Lang, M., and R. Lundholm. 1996. Corporate disclosure policy and analyst behavior. Accounting Review 71(4): 467-492.

13. Loomis, J. 2004. Watchdog says few make the grade. The Indianapolis Star (September 9): C3.

14. Marosi, A., and N. Massoud. 2004. Why do firms go dark? Working Paper: University of Alberta.

15. Nichols, D. 1989. The Handbook of Investor Relations. Homewood, IL: Dow-Jones-Irwin.

16. Uzun, H., S. Szewczyk and R. Varma. 2004. Board Composition and Corporate Fraud. Financial Analysts Journal 60(3): 33-43. 